\title{
Protein A/G-based enzyme-linked immunosorbent assay for detection of anti-Pythium insidiosum antibodies in human and animal subjects
}

Chalisa Jaturapaktrarak

Mahidol University Faculty of Medicine Ramathibodi Hospital

Penpan Payattikul

Mahidol University Faculty of Medicine Ramathibodi Hospital

Tassanee Lohnoo

Mahidol University Faculty of Medicine Ramathibodi Hospital

Yothin Kumsang

Mahidol University Faculty of Medicine Ramathibodi Hospital

Aree Laikul

Kasetsart University

Watcharapol Pathomsakulwong

Kasetsart University

Chompoonek Yurayart

Kasetsart University

Walaiporn Tonpitak

Mahanakorn University of Technology

Theerapong Krajaejun ( $\nabla$ mr_en@hotmail.com )

Mahidol University Faculty of Medicine Ramathibodi Hospital https://orcid.org/0000-0003-0545-3765

\section{Research note}

Keywords: Pythium insidiosum, Pythiosis, Immunodiagnosis, ELISA, Protein A/G

Posted Date: January 29th, 2020

DOl: https://doi.org/10.21203/rs.2.22143/v1

License: (c) (i) This work is licensed under a Creative Commons Attribution 4.0 International License.

Read Full License

Version of Record: A version of this preprint was published at BMC Research Notes on March 6th, 2020. See the published version at https://doi.org/10.1186/s13104-020-04981-y. 


\section{Abstract}

Objectives: Pythiosis is a deadly infectious disease caused by Pythium insidiosum. Reports of both human and animal pythiosis are on the rise worldwide. Prognosis of the pythiosis patients relies on early diagnosis and prompt treatment. There are needs for an immunodiagnostic test that can detect the disease in both humans and animals. This study aims at reporting an optimized protocol for the development of a protein A/G-based enzyme-linked immunosorbent assay (ELISA) for the detection of anti-P. insidiosum antibody in multiple host species.

Results: A total of 25 pythiosis and 50 control sera, obtained from humans, horses, dogs, cats, and cows, were recruited for the assay development. With a proper ELISA cutoff point, all pythiosis sera can ultimately be distinguished from the control sera. The successfully-developed protein A/G-based ELISA can detect the anti-P. insidiosum antibodies in serum samples of both humans and animals. It is a versatile and feasible-to-develop immunodiagnostic assay for pythiosis.

\section{Introduction}

Pythiosis is a deadly infectious disease caused by the pathogenic oomycete Pythium insidiosum [1, 2]. The disease affects humans and animals, especially horses and dogs. Geographic distribution of pythiosis covers the tropical and subtropical countries [2]. Pythiosis demonstrates high rates of morbidity and mortality [3]. Most of the affected individuals lose an infected organ, and many patients die from the disease. Prognosis of the pythiosis patients relies on early diagnosis and prompt treatment. Establishing the definitive diagnosis requires a reliable diagnostic method, i.e., organism isolation and identification, immunodiagnostic test, molecular assay, and proteomic analysis [1, 2, 4-13].

Immunodiagnostic tests for pythiosis have gained popularity due to simplicity and short turnaround time. Various immunodiagnostic methods, such as immunodiffusion (ID), enzyme-linked immunosorbent assay (ELISA), hemagglutination (HA), immunochromatographic test (ICT), have been developed to facilitate the diagnosis of pythiosis [10-20]. Each immunodiagnostic test has some advantages/disadvantages over the others. For example, ID and HA detect the antibodies in both humans and animals but possess limited sensitivity. ELISA is a multi-step assay but exhibits relatively-high diagnostic performance. ICT is a rapid and user-friendly assay, but the development of this test is complicated. Because reports of both human and animal pythiosis are on the rise worldwide, there are needs for an immunodiagnostic test that can detect the disease in a broad range of host species. Due to the lack of a versatile, feasible-to-develop, and functional immunodiagnostic assay, the current study aims at reporting an optimized protocol to develop an ELISA for the detection of anti-P. insidiosum antibody in humans and other animals. The assay relied on the use of protein $A / G$, which is a molecule that can bind the immunoglobulins from various animal species [16].

\section{Main Text}


We extracted proteins from the $P$. insidiosum strain Pi-S [21, 22], using the established method [17, 23]. In short, the organism was maintained on Sabouraud dextrose agar. Ten excised agar cubes $\left(\sim 0.5 \mathrm{~cm}^{3}\right)$ with $P$. insidiosum colony were incubated with shaking $(150 \mathrm{rpm})$ at $37^{\circ} \mathrm{C}$ for 10 days in $100 \mathrm{ml}$ of Sabouraud dextrose broth. The growing organism was removed from the cultured broth by consecutive filtrations through a filter paper (Whatman No.1) and a 0.22- $\mu \mathrm{m}$-pore-size Durapore membrane (Merck Millipore). The filtrated broth was concentrated by centrifugation $(10,000 \mathrm{x} \mathrm{g})$ with an Amicon Ultra $15 \mathrm{M}$ tube (Merck Millipore). The concentrated broth, now called culture filtrate antigen (CFA), was stored at -30 ${ }^{\circ} \mathrm{C}$.

We developed a multiple host-specific ELISA by modifying the human-specific ELISA protocols of Chareonsirisuthigul et al [15] and Lohnoo et al [23]. In brief, a 96-well flat-bottom polystyrene plate (Corning) was coated overnight at $4{ }^{\circ} \mathrm{C}$ with $100 \mu \mathrm{l} /$ well of CFA $(5 \mu \mathrm{g} / \mathrm{ml})$ in $0.1 \mathrm{M}$ carbonate buffer $(\mathrm{pH}$ 9.6) and $1.5 \% \mathrm{NaCl}$. The plate was washed 4 times with the washing buffer (phosphate-buffered saline $\mathrm{pH} 7.4$ [PBS] with $0.05 \%$ Tween-20) and blocked with $250 \mu \mathrm{l}$ of $0.5 \%$ bovine serum albumin (Merck) in PBS at $37^{\circ} \mathrm{C}$ for $60 \mathrm{~min}$. After the washing step (as above), a serum sample (1:1,600 in PBS) was added $\left(100 \mu \mathrm{l} /\right.$ well) and incubated at $37^{\circ} \mathrm{C}$ for $60 \mathrm{~min}$. After washing, $100 \mu \mathrm{l}$ of protein $\mathrm{A} / \mathrm{G}$ conjugated with peroxidase (Bio-Rad) $\left(1: 100,000\right.$ in PBS) was added to each well and stored at $37^{\circ} \mathrm{C}$ for $60 \mathrm{~min}$. The ELISA plate was washed once again. Chromogenic substrate $\left(3,3^{\prime}, 5,5^{\prime}\right.$-Tetramethylbenzidine and $\mathrm{H}_{2} \mathrm{O}_{2}$; Thermo Scientific) was applied to each well $(100 \mu \mathrm{l} /$ well) and incubated at room temperature for $3 \mathrm{~min}$ in a dark chamber. Sulfuric acid $(0.5 \mathrm{~N} ; 100 \mu \mathrm{l} /$ well) was used to stop the enzymatic reaction. Optical density (OD) of each serum sample was measured at the 450-nm wavelength.

A total of 25 serum samples from 20 humans, 4 horses and a dog with pythiosis, diagnosed in Thailand, were available for an assay evaluation. Control sera were derived from 50 healthy individuals with no sign of pythiosis ( 10 humans, 10 horses, 10 dogs, 10 cats, and 10 cows). Positive (from a known pythiosis patient) and negative (from a healthy blood donor) control sera were analyzed in parallel. All serum samples were tested in duplicate. ELISA value (EV) was an OD value of a serum sample divided by an OD value of the negative control serum. ELISA cutoff value was derived from the mean EV of the control sera plus 2, 3, 4, or 5 standard deviations (SD). Diagnostic performance (i.e., specificity, sensitivity, and accuracy) were calculated as described previously [15] (Table 1). Distribution of EVs (representing a detectable level of anti- $P$. insidiosum antibodies) of the pythiosis $(n=25)$ and control $(n=50)$ sera from both humans and animals was shown in Figure 1. Mean EV of the pythiosis sera was 41.0 (range, 23.146.9 ; SD, 5.2), whereas that of the control sera was 3.0 (range, 0.4-12.2; SD, 2.1). The "mean EV+5SDs" cutoff point provided the best sensitivity, specificity, and accuracy for the detection of the anti- $P$. insidiosum antibodies (Table 1).

With a proper ELISA cutoff point, all pythiosis sera can ultimately be distinguished from the control sera (Table 1; Figure 1). Unlike the species-specific ELISAs established by other investigators [10-15], the protein A/G-based ELISA is capable of detecting not only the anti-P. insidiosum antibodies in a single animal species, but also in humans and various animals (i.e., horses and dogs) those are the affected hosts of pythiosis. A key feature of our ELISA is the use of protein A/G (rather than a species-specific lgG) 
as a conjugate, which can bind the anti-P. insidiosum immunoglobulins from humans and other animal species. Recently, Intaramat et al. have developed the protein A/G-based ICT, as a rapid and user-friendly assay for diagnosis of pythiosis in humans and animals [16]. They performed a side-by-side performance comparison of their ICT [16] and the species-specific ELISA $[11,13,15]$ and showed that ICT has equivalent specificity but relatively-lower sensitivity. One major obstacle for clinical use of ICT is the assay production, which is very complicated and requires a skilled developer and some special reagents that are not available in general clinical laboratories. As opposed to ICT, although ELISA is a multi-step assay and has a longer turnaround time, the production of ELISA is more feasible and requires widelyavailable reagents. In conclusion, protein A/G-based ELISA has been successfully developed for immunodiagnosis of both human and animal pythiosis. It is a versatile, feasible-to-develop, and functional immunodiagnostic assay.

\section{Limitations}

The newly-developed protein A/G-based ELISA overcame the limitation of the previously-established ELISAs [10-15], as it can detect the serum anti-P. insidiosum antibodies in multiple host species, including the most affected hosts: humans, horses, and dogs. Other investigators could adopt our protocol to develop their own in-house ELISA. However, there are several limitations in association with the development and performance evaluation of the assay that need to be addressed:

1. The $P$. insidiosum strain Pi-S was used to prepare the coating antigen. Although this strain has been studied extensively [21, 22, 24], it is not available in the ATCC and CBS-KNAW culture collection centers. As we have regularly maintained the organism in the laboratory, it can be made available upon request. Alternatively, any other $P$. insidiosum strains could be used to prepare the coating antigen as well.

2. In the evaluation of our protein A/G-based ELISA, only pythiosis serum samples from 4 horses and a dog were tested, due to the low prevalence of the disease in animals in Thailand.

3. The current study focuses on reporting an optimized protocol for the development of protein A/Gbased ELISA. Thus, the diagnostic performance (i.e., detection sensitivity and specificity) of the assay was not extensively investigated, using a variety of serum samples from humans and animals with pythiosis and other diseases.

4. Like the previously-established ELISAs, one extra step to perform the assay is to make a serum dilution (our assay requires 1:1,600 dilution). This step is necessary for reducing the background ELISA signals from the bindings of non-specific antibodies and insidiosum's crude protein extract. In the future, if a purified $P$. insidiosum-specific protein is available for coating the ELISA plate, then an undiluted serum could be directly tested.

\section{Abbreviations}

CFA Culture filtrate antigen 
ELISA Enzyme-linked immunosorbent assay

EV ELISA value

HA Hemagglutination

ICT Immunochromatographic test

ID Immunodiffusion

OD Optical density

PBS Phosphate-buffered saline

SD Standard deviations

\section{Declarations}

\section{Ethics approval and consent to participate}

This work was approved by the Committee for Research, Faculty of Medicine Ramathibodi Hospital, Mahidol University (approval number: MURA2019/584).

\section{Availability of data and material}

The P. insidiosum strain Pi-S (for crude protein preparation) is available upon request.

\section{Funding}

The financial supports were obtained from Thailand Research Fund (T. Krajaejun; Grant number: RSA6280092), Faculty of Medicine, Ramathibodi Hospital, Mahidol University (T. Krajaejun; Grant number: CF_61007), and Royal Golden Jubilee Ph.D. Scholarship Program, Thailand Research Fund (C. Jaturapaktrarak; Grant number: PHD/0059/2561).

\section{Acknowledgements}

None.

\section{Consent for publication}

Not applicable.

\section{Competing interests}

None.

\section{Author's contributions}


Study design (CJ, TK); Experiment \& Methodology (CJ, PP, TL, YK, AL, WP, CY, WT, TK); Data collection (CJ, TL, YK, AL, WP, CY, WT, TK); Data analysis (CJ, PP, TK); Manuscript writing (CJ, TK).

\section{References}

1. Gaastra W, Lipman LJ, De Cock AW, Exel TK, Pegge RB, Scheurwater J, et al. Pythium insidiosum: an overview. Vet Microbiol. 2010;146:1-16.

2. Mendoza L, Ajello L, McGinnis MR. Infection caused by the Oomycetous pathogen Pythium insidiosum. J Mycol Med. 1996;6:151-64.

3. Krajaejun T, Sathapatayavongs B, Pracharktam R, Nitiyanant P, Leelachaikul P, Wanachiwanawin W, et al. Clinical and epidemiological analyses of human pythiosis in Thailand. Clin Infect Dis. 2006;43:569-76.

4. Krajaejun $T$, Lohnoo T, Jittorntam P, Srimongkol A, Kumsang $Y$, Yingyong W, et al. Assessment of matrix-assisted laser desorption ionization-time of flight mass spectrometry for identification and biotyping of the pathogenic oomycete Pythium insidiosum. Int J Infect Dis IJID Off Publ Int Soc Infect Dis. 2018;77:61-7.

5. Keeratijarut A, Karnsombut P, Aroonroch R, Srimuang S, Sangruchi T, Sansopha L, et al. Evaluation of an in-house immunoperoxidase staining assay for histodiagnosis of human pythiosis. Southeast Asian J Trop Med Public Health. 2009;40:1298-305.

6. Rujirawat T, Sridapan T, Lohnoo T, Yingyong W, Kumsang Y, Sae-Chew P, et al. Single nucleotide polymorphism-based multiplex PCR for identification and genotyping of the oomycete Pythium insidiosum from humans, animals and the environment. Infect Genet Evol. 2017;54:429-36.

7. Grooters AM, Gee MK. Development of a nested polymerase chain reaction assay for the detection and identification of Pythium insidiosum. J Vet Intern Med. 2002;16:147-52.

8. Keeratijarut A, Lohnoo T, Yingyong W, Rujirawat T, Srichunrusami C, Onpeaw P, et al. Detection of the oomycete Pythium insidiosum by real-time PCR targeting the gene coding for exo-1,3- $\beta$-glucanase. J Med Microbiol. 2015;64:971-7.

9. Vanittanakom N, Supabandhu J, Khamwan C, Praparattanapan J, Thirach S, Prasertwitayakij N, et al. Identification of emerging human-pathogenic Pythium insidiosum by serological and molecular assay-based methods. J Clin Microbiol. 2004;42:3970-4.

10. Mendoza L, Kaufman L, Mandy W, Glass R. Serodiagnosis of human and animal pythiosis using an enzyme-linked immunosorbent assay. Clin Diagn Lab Immunol. 1997;4:715-8.

11. Grooters AM, Leise BS, Lopez MK, Gee MK, O'Reilly KL. Development and evaluation of an enzymelinked immunosorbent assay for the serodiagnosis of pythiosis in dogs. J Vet Intern Med. 2002;16:142-6.

12. Keeratijarut A, Lohnoo T, Yingyong W, Sriwanichrak K, Krajaejun T. A peptide ELISA to detect antibodies against Pythium insidiosum based on predicted antigenic determinants of exo-1,3-betaglucanase. Southeast Asian J Trop Med Public Health. 2013;44:672-80. 
13. Santurio JM, Leal AT, Leal ABM, Alves SH, Lübeck I, Griebeler J, et al. Teste de ELISA indireto para o diagnóstico sorológico de pitiose. Pesqui Veterinária Bras. 2006;26:47-50.

14. Krajaejun T, Kunakorn M, Niemhom S, Chongtrakool P, Pracharktam R. Development and evaluation of an in-house enzyme-linked immunosorbent assay for early diagnosis and monitoring of human pythiosis. Clin Diagn Lab Immunol. 2002;9:378-82.

15. Chareonsirisuthigul T, Khositnithikul R, Intaramat A, Inkomlue R, Sriwanichrak K, Piromsontikorn S, et al. Performance comparison of immunodiffusion, enzyme-linked immunosorbent assay, immunochromatography and hemagglutination for serodiagnosis of human pythiosis. Diagn Microbiol Infect Dis. 2013;76:42-5.

16. Intaramat A, Sornprachum T, Chantrathonkul B, Chaisuriya P, Lohnoo T, Yingyong W, et al. Protein A/G-based immunochromatographic test for serodiagnosis of pythiosis in human and animal subjects from Asia and Americas. Med Mycol. 2016;54:641-7.

17. Jindayok T, Piromsontikorn S, Srimuang S, Khupulsup K, Krajaejun T. Hemagglutination test for rapid serodiagnosis of human pythiosis. Clin Vaccine Immunol. 2009;16:1047-51.

18. Pracharktam R, Changtrakool P, Sathapatayavongs B, Jayanetra P, Ajello L. Immunodiffusion test for diagnosis and monitoring of human pythiosis insidiosi. J Clin Microbiol. 1991;29:2661-2.

19. Mendoza L, Kaufman L, Standard PG. Immunodiffusion test for diagnosing and monitoring pythiosis in horses. J Clin Microbiol. 1986;23:813-6.

20. Krajaejun T, Imkhieo S, Intaramat A, Ratanabanangkoon K. Development of an immunochromatographic test for rapid serodiagnosis of human pythiosis. Clin Vaccine Immunol. 2009;16:506-9.

21. Rujirawat T, Patumcharoenpol P, Lohnoo T, Yingyong W, Lerksuthirat $T$, Tangphatsornruang $S$, et al. Draft Genome Sequence of the Pathogenic Oomycete Pythium insidiosum Strain Pi-S, Isolated from a Patient with Pythiosis. Genome Announc. 2015;3:e00574-15.

22. Rujirawat T, Patumcharoenpol P, Lohnoo T, Yingyong W, Kumsang Y, Payattikul P, et al. Probing the Phylogenomics and Putative Pathogenicity Genes of Pythium insidiosum by Oomycete Genome Analyses. Sci Rep. 2018;8:4135.

23. Lohnoo T, Yingyong W, Kumsang Y, Payattikul P, Jaturapaktrarak C, Chailurkit L-O, et al. Seroprevalence of anti-Pythium insidiosum antibodies in the Thai population. Med Mycol. 2019;57:284-90.

24. Krajaejun T, Rujirawat T, Kanpanleuk T, Santanirand P, Lohnoo T, Yingyong W, et al. Biochemical and genetic analyses of the oomycete Pythium insidiosum provide new insights into clinical identification and urease-based evolution of metabolism-related traits. PeerJ. 2018;6:e4821.

\section{Table}

Table 1. Correlation between the cutoff points and the diagnostic performance (i.e., sensitivity, specificity, and accuracy) of the protein A/G-based ELISA for detection of the anti-P. insidiosum antibodies in serum 
samples.

\begin{tabular}{|c|c|c|c|c|}
\hline Cutoff point $^{\mathrm{a}}$ & $\begin{array}{c}\text { Cutoff value } \\
\text { (EV) }^{\mathrm{b}}\end{array}$ & Sensitivity $^{c}$ & Specificity ${ }^{d}$ & Accuracye \\
\hline Mean EV + 2SDs & 7.1 & 100.0 & 96.0 & 97.3 \\
\hline Mean EV + 3SDs & 9.2 & 100.0 & 98.0 & 98.7 \\
\hline Mean EV + 4SDs & 11.3 & 100.0 & 98.0 & 98.7 \\
\hline Mean EV + 5SDs & 13.4 & 100.0 & 100.0 & 100.0 \\
\hline
\end{tabular}

Figures 


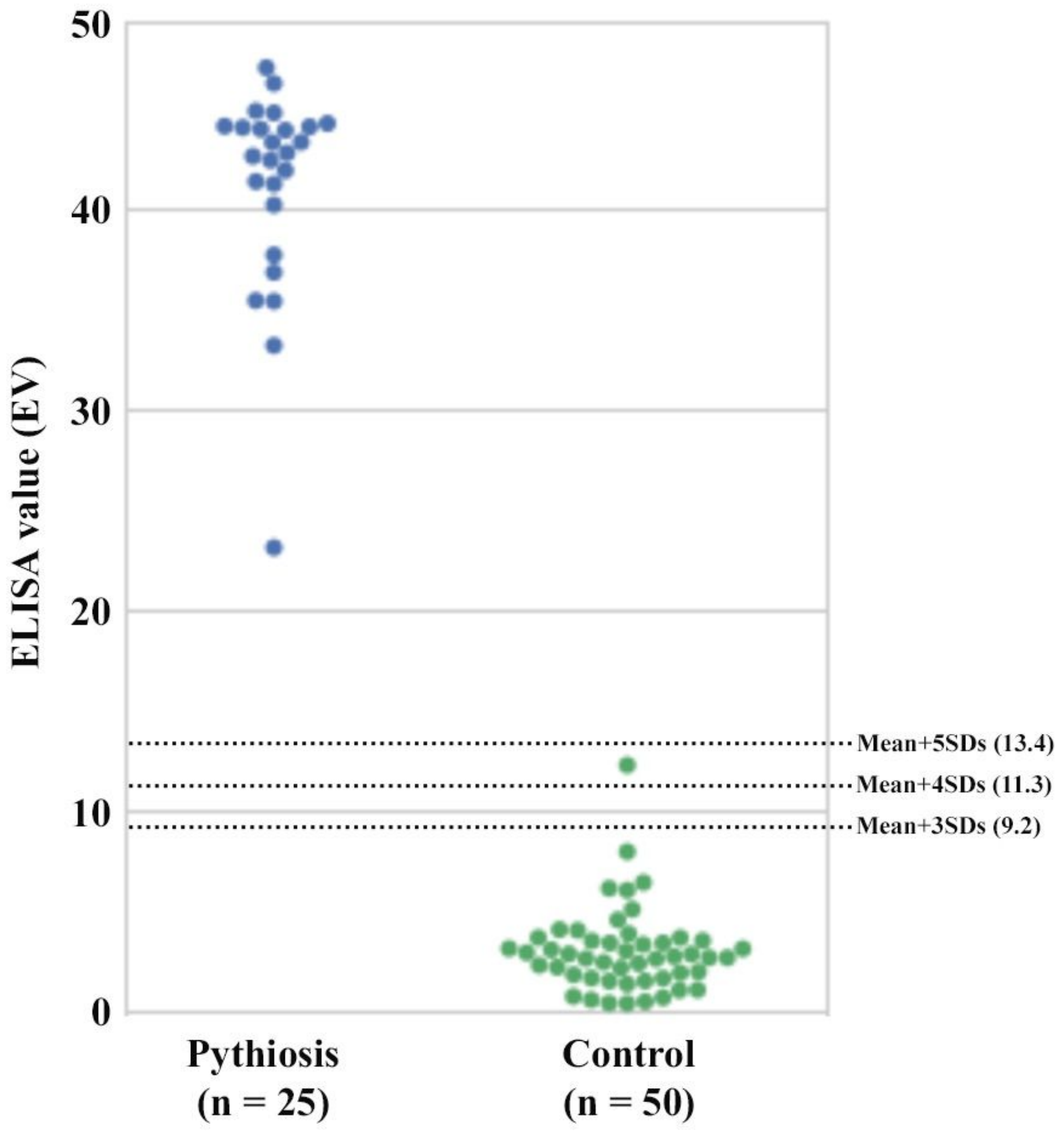

Figure 1

Dot plot of the ELISA values (EV) of pythiosis ( $n=25$; blue dots) and control ( $n=50$; green dots) serum samples. Dashed lines represent three different ELISA cutoff points, which is derived from the mean EV of the control sera plus 3,4 or 5 standard deviations (SD). 